\title{
Missionale integriteit en kontekstuele relevansie
}

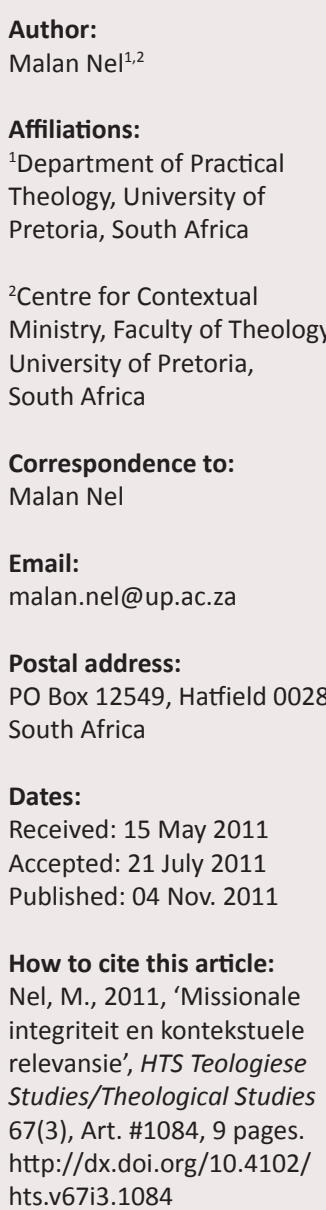

hts.v67i3.1084
C) 2011. The Authors. Licensee: AOSIS OpenJournals. This work is licensed under the Creative Commons Attribution License.

\begin{abstract}
Missional integrity and contextual relevance
The research problem addressed in this article discussed whether so-called missional local churches too often escape local contextual involvement by sending money or even people to work on their behalf 'elsewhere'. Is it true that local churches take the easier 'money-way' out to save a missional public face? The hypothesis is that missional integrity is in essence to be 'firstly' contextual relevant 'before' being nationally and even globally involved in mission. A basic assumption is that every local church is a gift of God to a specifically and even geographically defined context.
\end{abstract}

\section{Inleiding}

Om op hierdie wyse deel te neem aan 'n feesbundel vir Theuns Dreyer is 'n besonderse voorreg. Prof. Dreyer was reeds aan die Fakulteit Teologie verbonde toe ek in 1980 deel van die Departement Praktiese Teologie (toe nog van die Nederduits Gereformeerde (NG) Kerk se Fakulteit, Afdeling B) geword het. Ons ken-van-mekaar en deel wees van die vakvennootskap gaan ver terug. Ek dink aan hom as gewaardeerde vriend en kollega. Ek het baie respek vir hom as mens, teoloog en ook as leier in die denominasie waarvan hy deel is en waaroor hy so baie jare leiding geneem en gegee het - en steeds doen.

Die navorsingsprobleem wat in hierdie artikel aangespreek word, is die vraag na die verband tussen missionale ${ }^{1}$ integriteit en kontekstuele relevansie. Dié probleem hou my jare lank reeds besig. Ek pak dit hier aan onder meer omdat ek dink dat my verstaan van die plaaslike gemeente en die kerk as sodanig aansluit by wat ek meermale by prof. Theuns Dreyer gehoor het en ander kere op 'n afstand waarneem. Ek is deel van 'n denominasie wat op meer as een manier bekend is as 'n kerk wat ernstig is oor, wat lank so genoem is, die sending ${ }^{2}$. Ek is hierop nederig trots. Die gemeente waar ek kon begin was ook so 'n gemeente. Ek was die derde leraar en kon die vrugte pluk van voorgangers se bediening. Deel van hierdie bedieningsfilosofie (wat ek kon erf) was dat die kerkraad nie stem oor 'n sendingvoorstel nie, maar slegs binne sy vermoë betrokke raak. Ek het toe reeds iets kon leer van hoe radikaal missionale denke is. Pas 'n maand of twee na die ingebruikneming van 'n gemeentesentrum, met 'n redelike skuldlas vir 1969, kom daar 'n versoek dat die gemeente nie langer net ' $n$ evangelis in Nkensani ondersteun nie, maar ' $n$ volle leraarspos dra. In die kerkraadsvergadering vra ek dat ons hieroor moet stem. Die antwoord hierop is: 'Dominee, hierdie kerkraad stem nie oor sending nie. Ons keur die versoek eenparig goed.' Vir 'n jong predikant was dit Koninkryksmusiek.

Ek was vir my verstaan hiervan deur die ekklesiologie van twee voorgangers voorberei. Ek kon ook my bydrae lewer. In 'n baie klein geografiese omgewing rapporteer die voorsitter van die ouderlinge by die eerste vergadering na my ordening:

'In hierdie gemeente is 51 lidmate wat nooit meer die eredienste bywoon nie. Ons gee reeds as ouderlinge aan elkeen aandag, maar weet dat u ook graag sal wil help'.

Ek het probeer en minstens twee evangelisasie-ouderlinge opgelei. En ek kon mense, gesinne sien terugkom na God en die gemeente. Ek het nie toe woorde gehad vir wat ek hier as navorsingsprobleem probeer verwoord nie. Oor jare heen het dit egter gegroei. Dit het al vroeër in my lewe begin as jong lidmaat in die bediening van een van my Kloofsig-voorgangers, my teologiese opleiding het dit begrond en in die eerste gemeente het dit hande en voete gekry. Laat ek dit dan stel in woorde wat ek in 2005 die eerste keer soos volg gebruik het: Het gemeentes nie eers missionale integriteit wanneer hulle kontekstueel relevant is nie (vgl. Nel 2006b:11)?

My verstaan van die verandering in Suid-Afrika het ook my denkpatrone hieroor gevorm. Ek kon sedert 1988 vir 13 jaar aan die Universiteit Vista verbonde wees. In 1994, het ek pas die 1.Vir' $n$ huidige verstaan en gebruik van die term 'missionaal' in die Nederduitsch Hervormde Kerk in Afrika vergelyk Nel en Ungerer (2011).

2.Dit is nie hier die plek om hierop in te gaan nie, maar ek verwys graag na Saayman (2007) en Niemandt (2010) se refleksie op 'n deel van Saayman se verstaan van die bewegings in die sendinggeskiedenis van die NG Kerk. 
Sentrum vir Kontekstuele Bediening begin (November 1992). En ek leer hoe baie missionale hindernisse daar oor die jare heen teen kontekstuele betrokkenheid ontwikkel het en nog bestaan.

Die verhaal van 'n pastor het my so te sê finaal gehelp om die balans in hierdie dinamika anders te verstaan. Hy was in die eerste gevorderde kursus vir die opbou van 'n missionêre gemeente. Hy het my begin vertrou en op 'n dag 'n afspraak gemaak om 'n bedieningsvisie by my te toets. 'Die gemeente wil graag geld bele in die oprig van 'n radiostasie wat tot in Kenia gehoor kan word. Wat dink u?' 'X, wat doen julle waar julle is?' vra ek byna onmiddellik. $\mathrm{Na}$ ' $\mathrm{n}$ lang en ietwat ongemaklike stilte vra ek of ek iets gesê het wat ongemaklik is. 'Nee, Oom, maar jou vraag ruk my. Direk oor die straat waar ons kerkgebou is, lê 'n "squatter camp" en ons doen niks daar nie'. Omdat ons mekaar toe reeds goed geken het, vra ek: 'In alle liefde, hoe verwag jy dan dat mense jou in Kenia moet glo?'

\section{Missionale integriteit 'n Trinitaries-ekklesiologiese vertrekpunt}

Andries van Aarde neem in 2006 die opening van die Hervormde Teologiese Kollege waar. Sy referaat verskyn onder die titel 'Hoe om in te kom en hoe om binne te bly - die "groot sendingopdrag" aan die kerk vandag volgens Matteus 28:16-20' (Van Aarde 2006:103-122). Hy maak die stelling dat Matteus 28:19 in die Nuwe Testament dieselfde belangrike plek inneem as Deuteronomium 6:4 in die Ou Testament. Om dit in eie woorde ietwat populer te stel: as Matteus 28:19 sou verval, verval die Nuwe Testamentiese bestaansgrond van en vir die kerk. Hy wy 'n groot deel van die artikel aan die feit dat daar ' $n$ duidelike verband tussen Matteus 5:3 en Matteus 28:19 is. Mense wat weet hoe afhanklik hulle van God is, neem deel aan die maak van dissipels. Die verstaan van ons eie afhanklikheid, gebrokenheid en hulpeloosheid word byna voorwaarde tot die deelname aan die maak van dissipels. Dit is waarmee God (Drie-enig) besig is en waarmee Hy bedoel het dat die kerk besig behoort te wees. Dit is skeppingsbedoeling.

'n Missionale verstaan van die kerk gaan inderdaad terug op die skeppingsbedoeling van die mens. In die eerste skeppingsverhaal is dit duidelik: die mens is geskape om as verteenwoordiger van die Skepper die aarde te versorg. Juis hierdie doel mis die mens. Dit is ons mislukking. Reeds in die Ou Testament word God se herskeppende werk duidelik. Die Psalmdigter reflekteer hierop in byvoorbeeld Psalm 8 . En die Evangelie klink toe reeds dat hierdie mens, skaars minder as 'n hemelse wese, oor 'die werk van $u$ hande' (vs 7) heers. Met hierdie herstel van die mens gaan God in Christus voort. Die mens kry sy lewe terug om in diens van die doel van sy lewe, te leef. En die Nuwe Testamentiese kerk is uitdrukking van hierdie groep heelwordende mense (Matt 5:3) wat weer die doel van die lewe teruggevind het: om in navolging van en lerende van Jesus die lewe in sy volle omvang te leef. Kiefert (2007:53) beskryf die gemeente as mense op reis binne-in, te midde van, die werklikheid van God Drie-enig.
In die hart van hierdie belydenis van kerkwees lê dan Deuteronomium 6:4 - erkenning en belydenis dat die Here die enigste en unieke Een is. Niemand kan dit bely behalwe deur die Heilige Gees nie (vgl. 1 Kor 12:3). Die belydenis dat Jesus die Christus, die Seun van die lewende God is, word die mens gegee. Dit kom van buite ons om te erken dat God God is en dat ons syne is.

Hierdie verstaan van kerkwees neem die 'ons' van 'my' menswees ernstig op. Die mens is nie alleen nie en 'een' is nooit ten volle wat ons bedoel is om te wees nie. Die kerk as Trinatriese skepping is korporatief te verstaan. Dit is 'n 'ons'-werklikheid. Dick (2007:92) vind in sy ondersoek na 717 gemeentes dat gemeentes wat tegelyk stabiel en groeiend is, so oor hulleself dink: "“We" is the word spoken most frequently in vital congregations.' Identiteitsvinding binne ' $n$ Trinitariese ekklesiologie is onder meer die vind van ons meervoudige wese. Om terug te gryp na Van Aarde se verstaan van dissipels maak, sou ons kon sê: dissipels (meervoud) maak dissipels.

Hierdie belydende gemeenskap vind veral plaaslik gestalte. Die werklikheid van ons geskapenheid as groep nuwe mense is baie groter en moet as sodanig bely word. Ons glo aan een algemene, heilige, Christelik kerk. Die gesig en die gestalte van hierdie werklikheid is egter allereers plaaslik ervaar- en waarneembaar.

\section{Ingeskakelde kerk}

Die kerk is nie maar geskep nie, maar met bedoeling geskep. Die kerk is deel van God se bedoeling om te herstel. Hiermee het die heilswerk van God Drie-enig alles te doen. Ons is herskep en word tot deelname aan die heelwording van die skepping bewoon. Die Gees wat oor die water sweef, is die Gees wat ons bewoon terwyl Hy skep en tot orde herskep. Wat die Vader in Christus gedoen het (Christologiese verlede tyd) word deur sy inwoning gedoen - herskeppende teenwoordige en toekomstige tyd. Christologies is ons eenmaal uitgeskakel om nou pneumatologies vir altyd ingeskakelde mense te wees (vgl. Bohren 1974:65-88; Dingemans 1986:41-52). Ons kon nie, maar nou kan ons (vgl. Hand 1:8).

Dit was Van Ruler (1969:181, 1973:12, 28-29, 36-37) wat 'n begrip wat ook hier ter sake is, gebruik het, naamlik Theonome resiprositeit. Hy beskryf daarmee die dinamika van ons deelname aan dit waarmee God in sy genade besig is:

What in Christology is called substitution is called reciprocity in Pneumatology. The Holy Spirit restores a relationship through the Mediator and with our Creator where we begin to understand our role as coworkers with and of God. The significane of the work of the Holy Spirit is that He puts us to work. Our total existence begins to bear the mark of the work of the Father, Son and Holy Spirit.

(Nel 2009b:8)

Die geskepte nuwe werklikheid, die kerk, is deur die werk van God, die Gees, ingeskakelde kerk. Ek het elders die metafoor van soekgeselskap gebruik. Ons wat in ons eie wegkruipplek gevind is, vind nou die ander, die wat nog 
weg is (vgl. Luk 15). Ons word ook tegelyk dié wat wag op hulle wat terugkom. Nouwen (1994:134-139) is waarskynlik korrek wanneer hy beweer dat ons nie die gelykenis van die verlore seun (of van die wagtende vader) verstaan, voordat ons nie onsself in al drie die hooffigure herken nie. Dit is byna logies dat hierdie werklikheid (van ingeskakel te wees) hom allereers kontekstueel afspeel. Hierdie bogenoemde korporatiewe ons soek plaaslik, kla plaaslik oor geld wat aan soek en ontvang bestee word en tree kontekstueel op as 'receiving fellowship' (Kromminga 1964:251) en as 'receptive fellowship' (vgl. ook Kromminga 1976:160).

Natuurlik is die soektog wêreldwyd. Dit is immers waar God se hart en bedoeling lê (vgl. Joh 3:16). Sy bedoeling met sy wêreldwye betrokkenheid van die kerk is wel dat daar nuwe plaaslike soekgeselskappe gevorm word wat weer self missionale integritiet deur hulle plaaslike en kontekstuele relevansie verkry. Soveel so dat ons waarskynlik sou kon sê: gemeentes wat langs hierdie weg plaaslike missionale integriteit het, het ook integritet wanneer hulle buite eie konteks deelneem aan die soeke waarmee God wêreldwyd besig is. As die 'wêreld' (wat nog gesoek word) 'n sê sou hê in die toelating van sendelinge tot hulle lande, sal hulle waarskynlik vra dat gemeentes met kontekstuele relevansie en plaaslike integriteit, kom deelneem aan die soeke na hulle wat nog weg is in hulle omgewings en lande.

\section{Omgewingsvriendelike geskenke}

Terwyl die kerk 'n Trinitariese werklikheid is, terwyl dit kosmologies bedoel is, is dit plaaslik, byna geografies geskenk. Die geadresseerde karakter van die gemeentebriewe in die Nuwe Testament is hiervan maar net een bewys. Gemeentes het adresse, fisiese en geografies aanduibare adresse. Die geskenk van God is geadresseerd, aflewerbaar. Binne die reformatoriese tradisie van byvoorbeeld die NG Kerk in Suid-Afrika is daar min, indien enige vierkante kilometer wat nie binne die grense van 'n plaaslike gemeente van die NG Kerk val nie. Dit is ook van ander denominasies waar. Dit is jammer dat hierdie sogenaamde grense hierdie missionale funksie verloor het en dat in die debat oor grense, wat van tyd tot tyd nog opvlam, grense 'n saak op sy eie geword het (en meermale as beskerming van belange dien).

Die plaaslike gemeente is bedoel om 'n omgewingsvriendelike geskenk te wees. Daar is nou tegelyk 'n verteenwoordiger van die heil wat God skenk en 'n ekologiese agent in die gemeenskap (vgl. Conradie 2010:380-396 vir sy verstaan van Creation at the heart of mission). 'n Dienskeg (korporatief) van God het onder ons kom woon in woonbuurt X, distrik Y, provinsie Z (vgl. ook Brouwer 2009:407 vir sy verwysing na die gemeente se ekologie en sensitiwiteit vir die deelwees van die gemeenskap).

\section{Kontekstueel uitgedaag Kontinuïteit en diskontinuïteit}

Binne die Suider-Afrikaanse konteks is die uitdagings divers. Daar is baie kontinuiteit soos byvoorbeeld ten opsigte van veiligheid. Meeste, indien nie almal nie, beleef meermale en selfs dikwels 'onveiligheid'. Mense uit alle bevolkingsgroepe is werkloos, en is byvoorbeeld arm. So ook is mense uit alle bevolkingsgroepe ryk, maar tog soms lewensarm. Daar is inderdaad baie gelykhede in die landwye uitdagings.

Terselfdertyd is daar diskontinuïteit. Sommige woonbuurtes ken net armoede, water- en ligte-loosheid. Nog ander is opvallend sonder 'n dak oor die kop. Soms is die andersheid van ons nood 'n straatbreedte ver. Enigeen wat oop oog deur hierdie land ry, merk dit op. Dit is meermale ironies hoe die uitdagings oor die straat heen, oor die hoofpad heen, anders is.

Iewers lê nie net die gemeentesentrums van hierdie land nie, maar tussen alles en almal heen woon die lidmate van hierdie gemeentes. Dit is nie die plek om in hierdie artikel die algemene nood van hierdie land op te som nie. Dit is wel binne die doel van hierdie artikel om te beklemtoon dat niemand presies weet wat die uitdagings is, behalwe binne die geografiese en sosiale konteks van ' $n$ bepaalde gemeente nie. Oor die kontinue ('ons het almal nood') kan maklik veralgemeen word. Vir missionale kontekstualiteit behoort die diskontinue ('so is dit by ons') gespesifiseer te word. Deur middel van kontekstuele en omgewingsdiagnoses behoort so bepaal te word wat die uitdagings is (vgl. Hendriks 2004:69-103 vir sy hoofstuk oor A contextual analyses: The ecology of the congregation).

\section{Konteksanalises}

Missionale gemeentes doen moeite om die konteks te lees en te probeer verstaan (vgl. ook Niemandt 2010:99-100). Binne 'n kontekstuele verstaan van die Evangelie van die Koninkryk is die wêreld eweseer 'n geskenk van God aan die kerk as andersom. Blauw (1962) het dit reeds raakgesien in sy refleksie op die Ou Testament:

All the emphasis falls on the fact that the world of nations is a gift to the Messianic Servant; there is no reference here to the world as a 'mission territory' of the Servant.

(Blauw 1962:15-54)

Hierdie teks lees waarkynlik net soos die Bybel as teks ietwat makliker wanneer dit as geskenkte teks waardeer word. Juis hierin kom die liefde vir die wêreld as geskape en geskenkte werklikheid tot openbaring, deur respek vir die tweede teks, die konteks. Soos eksegese vir die prediking is konteksanalises vir missionale kerkwees (vgl. Nel 2009a, 2009b). Dit breek die 'teks' tot spreke oop. Dit word 'n hermeneutiese gebeure. Verstaan vind plaas. Horisonne versmelt. Die 'church on the other side' (Mclaren [1998] 2000:121-143) ervaar die heil wat heelmaak en die gemeente self (of sou ons kon sê die 'church on the inside') ervaar die heelmaking van die missionale heil.

\section{Morfologiese fundamentalisme (Hoekendijk)}

Wanneer gemeentes hiervoor terugdeins, soos wat sommige predikers vir eerlike eksegese terugdeins, steek 'n ander vorm van fundamentalisme sy kop uit. Verkuyl (1978:96 met erkenning aan Hoekendijk) noem dit ook 'verstarring' 
en veral van strukture. Dit gebeur meermale wanneer die gemeente onveilig voel in sy konteks (waaraan hulle geskenk is en wat aan hulle geskenk is) en binne kultuurvorme sekerheid soek en selfs dink dat hulle sodanige sekerheid vind. In missionale denke en literatuur word vir hierdie gemeentes se verandering selfs nie meer die begrip reformasie gebruik nie, maar 'redevelopment' - met die implisering van sloping en herontwikkeling. Sellon, Smith en Grossman (2002:x-xii) onderskei tussen 'renewal, revitalisation and redevelopment'. Hoe gouer die gemeente besef dat 'they are disconnected from their communities, the "simpler the return to health"':

When the bulk of the congregation's focus is still outward, we think of the shift back as church renewal ... Revitalization is what the journey is called when the church's disconnect with the surrounding community increases and the energy has turned more towards maintenance and preservation ... Redevelopment is what the journey is called when the congregation has fundamentally congealed. The church has now become primarily focussed on preserving the status quo.

(Sellon, Smith \& Grossman 2002:xi; vgl. ook Nelson 1988a:1-19; Harris 1988:238-264)

Dick (2007:15-41) bevind op grond van sy empiriese studie van 717 gemeentes dat 50\% van hierdie gemeentes tegelyk kwyn en baie onstabiel geword het. Hy vra verskoning vir die benaming, maar het die moed om dit as 'decaying' te beskryf: ' $n$ toestand na die dood reeds plaasgevind het. Dit sou 'n staat van ontbinding genoem kan word.

Hierdie uitdaging is groot. Dit het ten diepste te doen met die gemeente se verstaan van hom- of haarself. Dit daag ons uit om aan die kerk as missionaal in wese te dink. Dit vra moed en soms jare van worstel om te bely: die gemeente is kontekstueel missionêr of dit is nie gemeente of kerk nie. Daar is nie ' $n$ 'ander' soort gemeente nie, een wat byvoorbeeld met 'sending' as een van sy bedieninge besig is nie. Die gemeente is in wese en funksie God se sending. Om dit saam met Bosch (1991:9) te sê: 'This dimension of the Christian faith is not an optional extra: Christianity is missionary by its very nature, or it denies its very raison d'être.' Binne die konteks van die Afrikaanssprekende kerke is hierdie uitdaging miskien selfs meer krities. Hamman (2005) dink dat die verlies van apartheid vir blanke Suid-Afrikaners nie regtig met treur en veral rou gepaard gegaan het nie en daarom baie lidmate vashou, soos wat treur mense in die verlede vashou. In 'n onlangse proefskrif het Boshoff (2011) hierdie teorie in drie gemeentes van die NG Kerk kwalitatief ondersoek en die navorsingshipotese bevestig dat die onverwerkte verlieservaring inderdaad die opbou van 'n missionêre gemeente in sy wese beïnvloed. Die bedreiging van morfologiese fundamentalisme as strukture en vorme waarbinne mense wat verlies ervaar veilig voel, staar gemeentes vierkantig in die oog. My eie empiriese betrokkenheid by gemeentes wat doelbewus die gemeentebou proses aanpak, bevestig watter uitdaging dit is om 'n gemeente tot 'n nuwe en missionale verstaan van hulleself te begelei. Sewentien predikante beskryf iets hiervan in Stories van hoop (Nel 2006a).

\section{Kontekstuele Koninkryksoekers}

Wat sou nou die oriënteringspunt vir missionale kontekstualiteit wees? Schippers (1982:96-105) het al in aansluiting by Barth geskryf dat Christus die oriënteringspunt van kerkwees is. Die gemeente behoort besig te wees waarmee Hy besig was: die hierwees en die deurbreek van die Koninkryk van God. Hy verkondig 'die evangelie van die Koninkryk' (Luk 8:1).

\section{Die konkretisering van die heil}

Die evangelie van Lukas help ons met ons verstaan van die konkrete heil wat in die koms van die Koninkryk sigbaar word (vgl. veral Luk 7:18-23). Die dissipels van Johannes die Doper vind Jesus 'juis' besig om 'mense gesond te maak van siektes en kwale en bose geeste ...'. Op die vraag of hulle iemand anders moet verwag, het Hy een antwoord: 'Gaan vertel wat julle gesien en gehoor het ...' Die konkreetheid ruk ons tot kontekstuele nugterheid. Aan hierdie werklikheid kan net die konkrete gemeente kontekstueel deelneem. En aan hierdie kontekstuele konkretisering van die evangelie van die Koninkryk neem mense deel wat juis langs hierdie selfde weg deel gekry het aan die heil: die twaalf en ' $n$ 'aantal vroue wat van bose geeste en siektes genees was. Daar was Maria, bekend as Magdalena, uit wie sewe duiwels uitgegaan het ...' (Luk 8:3). Wie vergeet hoe 'beduiweld' ons was, kan eintlik nie sinvol deelneem aan en betekenis gee aan die soek van die Koninkryk nie.

\section{Die verstaan van die Koninkryk en kontekstuele relevansie ${ }^{3}$}

Die Koninkryk kan alleen teen die agtergrond van God se konkrete betrokkenheid by die skepping verstaan word. Hierdie eeue-oue betrokkenheid van God by sy skepping word vlees in Christus. Hierdie aardsheid en vleesheid van die teologie van die inkarnasie vind uitdrukking in die Bybel se boodskap oor die Koninkryk van God. Tereg skryf Armstrong (1987:62) dat 'this powerful concept, has been unfortunately neglected in the teachings of many churches'. Sy eie definisie van evangelisasie soos in 1979 ontwikkel (1987:15) en dié van Verkuyl (1978:51) is van die eerstes waarvan die skrywer hiervan weet wat direk die begrip 'Koninkryk van God' in 'n definisie van evangelisasie insluit.

Dit is nie hier die plek om breedvoerig oor die betekenis van die Koninkryk te handel nie. Kortliks word in belang van die sentrale tema van hierdie artikel verwys na die verband tussen die Koninkryk van God en die sjalom Jahve [vrede van die Here] in die Bybel. Wat breek nou eintlik deur in en met die koms van die Koninkryk in die vleesgeworde Christus? Heil breek deur: die vryspraak van sonde is 'n werklikheid, versoening en herstel van verhoudings met God en mens is moontlik, God-verlatenheid is opgehef, die magte wat die lewe van mense fnuiken soos dood, sonde en 'demone' het nie meer die laaste sê nie, vrees vir die magte kom tot 'n einde. Mense dien God omdat hulle vry is en nie omdat

3.Die skrywer het vir die volgende paragrawe vrylik gebruik gemaak van navorsing uit 'n vorige artikel (Nel 2007:98-117). 
hulle bang is nie. Die Koning is Vader en roep tot diens wat bevrydend is:

Om die wat onregverdig gevange gehou word, te bevry, om die juk wat op mense druk, af te haal,

om verdruktes vry te maak,

om elke juk te breek?

Is dit nie dat jy vir dié wat honger is, van jou brood gee nie,

dat jy aan die armes en die dakloses 'n blyplek gee nie,

dat wanneer jy iemand sonder klere sien,

jy vir hom klere gee nie,

dat jy jou medemens

nie aan sy lot oorlaat nie?

(Jes 58:6-7)

Dit is die voortdurende ontdekking van die radikaliteit en die aardsheid van die Koninkryk wat ons ook help om die doel van ons missionale 'syn' te herontdek. Wat bring Christus wat ander godsdienste nie ook maar kan bied, of selfs beter kan bied nie? In 'n artikel bedoel om die agenda van 'n 1984-konferensie van Britse Kerke se agenda te bepaal, skryf Newbigin (1983:56-60) dat vier vrae op die tafel is: 'what it means to be a human person, what is the goal of human life, ... what is our vision of the future'. (Sy vyfde vraag raak die vraag na ken en kennis. Hoe benader ons 'weet' in die toekoms?)

Dit is die boodskap van die evangelie van die Koninkryk wat die navolging van Christus anders en selfs uniek maak. Dit is die verlossingsleer van die Skrifte. Enigiets wat hier weggelaat word, begin om die evangelie tot 'n karikatuur te omvorm. Dit is juis hier waar kort paaie tot 'evangelisasie suksesse' die begin van langtermyn mislukkings is. Evangelisasie vanuit 'n Koninkryksperspektief omvat die hele lewe, want dit staan in verband met die totale Ryk van God (vgl. Verkuyl 1978:19). Binne hierdie verstaan is dit moontlik om twee waarhede tegelyk vas te hou: dit gaan basies om 'n nuwe en lewegewende verhouding met die Koning en om 'n betrokkenheid by die verweefdheid van getuienis, gemeenskap, diens en bevordering van die reg van God. Hierdie laaste dimensie word dikwels met die 'social gospel'-benadering verwar. Armstrong (1979) was binne die konteks van sy tyd reg deur te sê:

social action is the natural consequence of service evangelism, but not vice versa ... It is not possible, in my opinion, to be meaningfully involved in service evangelism without being involved in social action.

(Armstrong 1979:58)

Verkuyl (1978:19) eindig 'n paragraaf met dieselfde strekking so: 'Niet woorden en argumenten zijn het zaad van het Rijk Gods, maar de kinderen des Koninkrijks zelf, verstrooid over de aarde en gezaaid in het veld' (vgl. ook Nel [1997] 2000:69-75 vir 'n kort refleksie hierop binne die doel van Jeugbediening). In die woorde van Blauw (1962):

the evangelization of the world is not a matter of words or of activity, but of presence: the presence of the people of God in the midst of humanity, the presence of God among His people.

(Blauw 1962:43)

In Verkuyl (1978:51) se omskrywing van evangelisasie beklemtoon hy hierdie omvattende betrokkenheid van die gemeente by die kommunikasie van die evangelie van die Koninkryk van God vanuit die hele gemeente in sy eie omgewing deur die kommunikasie van die evangelie, deur gemeenskap, deur diens en 'door participatie in die worsteling om gerechtigheid'. In 'n latere bydrae skryf Verkuyl (1993):

A Kingdom-centered theology worthy of its name is concerned with every aspect of life and society. Often in the history of the church and theology Jesus has been - and in some cases continues to be - proclaimed without His Kingdom ... The kingdom addresses itself to all human need, both physical and mental.

(Verkuyl (1993:72); vgl. ook Berneburg 1997:200f; Ekström 2003:292-305)

Bosch (1991:10-11) se bekende verwysings na 'mission' as tegelyk God se 'ja' vir die wêreld en sy 'nee' vir die wêreld bou op 'n verstaan van die Koninkryk en van die Missio Dei. In sy 1993 bydrae in die werk van Van Engen en ander kom hy tot die volgende gevolgtrekking:

in the long run, a society, any society, can only survive if it can rely on the assumed virtue of its citizens. This means that even a pluralist or secularist society will remain dependent upon the witness and existence of believers, that is, of persons whose integrity and good conduct can be relied upon. It is only a shared moral vision that can hold society together (cf. Walzer 1966:302f). If we can continue to contribute to this vision, our mission will be a blessing to all.

(Bosch 1993:95)

Bradshaw $(1993: 49,87,99,113,125,151,163)$ beskryf sjalom [vrede] as die brug tussen ontwikkeling en evangelisering. Die evangelie van die Koninkryk het inderdaad te doen met: 'Contextualization, education: Liberating and empowering people, caring for creation, economics, healing, holism, transformation.' In die woorde van Newbigin (1995:30e.v.) en om uitdrukking te gee aan die Trinitariese verstaan van die evangelie van die Koninkryk 'mission is ... Faith in action (proclaming the kingdom of the Father), Love in action (sharing the life of the Son), Hope in action (Bearing the Witness of the Spirit' (vgl. ook Bosch 1991:498-510 se beskrywing van 'Mission as Action in Hope').

Hierdie teologiese vertrekpunt (sjalom, soos dit in die Koninkryk gestalte vind) gee hande en voete aan missionale kontekstualiteit en relevansie. Dit behoort ons na twee kante af te grens en te bewaar van 'n teologie wat klink asof dit in die hemel geskryf is en aan die anderkant van 'n praktyk wat miskien uit' $n$ ander plek kom. Prakties Teologies kan dit soos volg gestel word: dit bring die teologiese teorie en praktyk teorie bymekaar. Daar mag immers nie wegkruipplek gebied of geskep word vir gemeentes met teorie sonder praktyk, of andersom nie. Evangelistiek en/of Missiologie sonder teorie van praktiese kommunikasie, is die beskrywing van 'n skip wat in die dokke lê (vgl. Verkuyl 1978:51). Hunsberger (1998:113e.v.) koppel in sy bespreking van Newbigin, laasgenoemde se teologiese verstaan van die Koninkryk aan 'the clue to the Meaning of History' (1998:114). Was dit nie nog altyd die begrip wat die uitdrukking wou gee aan God se kultureel-kontekstuele teenwoordigheid in sowel 'n sekulêre en pluralistiese wêreld nie? 
Dit is my oortuiging dat Gibbs (2000) se beskrywing van 'ten quantum changes in how we do ministry' onder die een noemer van 'die herontdekking van die betekenis van die evangelie van die Koninkryk' geplaas kan word. Hy reflekteer juis hierop in sy bespreking van die tweede verandering wat hy waarneem, naamlik van 'market driven to mission oriented' (2002:36-64). Dit is in hierdie verband dat hy byvoorbeeld die komplekse werklikheid van kontekstualisering bespreek:

The choice facing the church is not between assimilation and isolation. It must see beyond that dilemma, moving towards a position of critical contextualization. This complex task is further complicated by the fact that the church itself is immersed in the culture. This means that it is both the subject examining the situation and the object of that examination. The missional church recognizes the dynamic interplay of church, gospel and society.

(Gibbs 2002:51)

\section{Teologiese gevolge van twee vertrekpunte Dissipelskap en dissipelering}

Die verlies van hierdie sentrale insig van dissipelering in missionale en Koninkryksdenke hou verband met die verskraalde verstaan van bekering as doel van evangelisering. Prill (2005:314) verwys na Abraham (2001:103) wat in die plek van die ander modelle pleit dat 'evangelism should be construed as initiation into the kingdom of God'. Hierdie benadering is ' $n$ poging om weer die Bybelse verstaan van dissipelskap terug te bring in ons verstaan van missionering. Dit is die rol wat die kategese in die vroeë kerk gespeel het, naamlik inlywing in die gemeenskap van navolgers (leerlinge) van Christus. Aksies in hierdie verband sluit in: verkondiging van die evangelie, die oproep om berou te hê, te bely en in Christus te glo, basiese onderrig in Christelike teologie en waardes, die doop en deelname aan die geloofsgemeenskap.

Dit gaan dus om 'n teologiese verstaan van die gemeente as 'n gemeenskap van dissipels en as 'n dissipel-gemeenskap, met geweldige implikasies vir die ekklesiologie. Die gemeente is nie maar net mense wat 'gekies' het vir Christus nie, maar mense wat Hom volg, van Hom leer om nuwe mense te wees en nuwe lewens te leef in hulle eie wêreld. Dit het minstens tot gevolg:

- 'Verlossing wat persoonlik sowel as korporatief, fisies sowel as geestelik verstaan word. King (1996:83 soos aangehaal in Prill 2005:323) vertel die verhaal van 'n werker van die Heilsleër wat saam met 'n biskop in 'n trein gereis het. $\mathrm{Na}$ 'n rukkie het die werker hom verplig gevoel om die biskop te vra of hy gered is. Die biskop se antwoord het hom redelik onkant gevang: 'It depends what you mean. I have been saved, I am being saved, and I will be saved'.

- Dat bekering sowel ' $n$ keuse as ' $n$ proses is. Navorsing wys in die rigting dat mense oor 'n langer tyd gelowiges word. Terwyl bekering lank verstaan is as ' $n$ omdraaipunt op 'n bepaalde oomblik, is daar al meer klem op die proses. 'In other words, finding faith is seen as a process and not as an event' (Prill 2005:327; Moynagh 2001:113). Dit pas in by die herontdekking van die teologiese perspektief van dissipelskap binne evangelisering. Binne die gereformeerde tradisie word bekering ook verstaan as keuse en as proses van danksegging vir die heil (vgl. Heidelbergse Kategismus, Deel 3).

- Die betrokkenheid by 'n gemeenskap van dissipels wie se eerste besigheid die ywerige soek van die Koninkryk is. Dit relativeer die gemeente of kerk tot 'n gemeenskap sonder eie belange. Dit beklemtoon die relevansie van die gemeente of kerk aan die anderkant as verkore agent van die Koninkryk. Dit lei tot nederigheid by almal wat as dissipels self nog tot bekering kom en tot egte dankbaarheid dat juis hierdie dissipels (in wording) deelneem aan die proses van dissipelering. Hierdie navolging omsluit die heelwordende lewe van mense wat by Hom heelheid vind. Missionering vanuit dissipel- en Koninkryksperspektief wil holisties verstaan word: dit is omvattend en help mense om geïntegreerde lewens terug te vind en lewenslank daaraan te bou (vgl. Verkuyl 1978:50).

Dit is in hierdie verband belangrik om 'n oomblik stil te staan by die Nuwe Testamentikus Andries van Aarde (2006:103-122) se openingsrede. Hierdie goedgedokumenteerde artikel kan nie in die beperkte ruimte van hierdie artikel volledig verdiskonteer word nie. Enkele opmerkings oor die belang van die insigte vir die onderwerp onder bespreking is ter sake.

Die gemeente moet haarself anders verstaan. Aansluitend by insigte van talle ander, skryf Van Aarde (2006) dat ons:

in vandag se wêrelddorp nie te doen het met ons hier en die heidene/ongelowiges daar nie. Die indeling van mense tussen 'gelowiges' en 'ongelowiges' is te gekompliseerd om so 'n eenvoudige onderskeid te tref.

(Van Aarde 2006:105)

Hy verwys dan onder andere na McLaren ([1998] 2000:121-143) wat na die tradisionele 'buitekerklikes' verwys as 'the church on the other side'.

Volgens Van Aarde wil Matteus ons help om te verstaan dat dissipels mense is wat nie 'in' is omdat hulle reg gedoen het nie. Die Ou Testamentiese verstaan van die verbond word in die dissipelskapterminologie vasgehou. God het ons ingebring en binne onthou ons dit. Die begrip van God se geregtigheid word dan behandel. Dit is God 'wat regstellend handel deur reg te maak toe Israel nie in staat was om die wat buite was, in te bring nie' (2006:110). Dit is juis die boodskap van Matteus dat hierdie 'outsiders', mense van wie niemand kennis neem nie, egte 'outsiders' die Koninkryk beërf (vgl. die rol wat Matt 5:3 in die verklaring van die Evangelie speel). Van Aarde (2006:111) stel dit so: 'Wat betref die inkom in die kerk deur die sogenoemde "outsiders", dink Paulus en Matteus dieselfde, hoewel uitgedruk op eie genuanseerde wyse.' Dit is hierdie dialektiese waarheid van wat dit beteken om tegelyk oud en nuut te wees wat in die verstaan van die 
gemeente verlore gaan wanneer die evangelie en kerkwees kulturele goed word. Van Aarde verwys dan na Barth (1932:206) se oproep aan gelowiges, naamlik:

tot' $n$ dialektiese spanning om nooit die evangelie gelyk te stel aan kulturele konvensie nie, om nie sending as kultuurpropaganda te sien nie - net soos Paulus in Romeine 10:3 van Israel vra om nie eie-geregtigheid God se geregtigheid te noem nie.

(Van Aarde 2006:112)

Van Aarde (2006) merk dan op dat dit juis hierdie soort sensitiwiteit is wat ons in die groot sendingopdrag kry:

Die opdrag is 'groot' want dit is nie net die uitspel van Jesus se 'groot' liefdesgebod nie, maar eintlik die samevatting van die hele Evangelie van Matteus. Die inklusiewe karakter van kerkmense se gesindheid kom tot uitdrukking in die 4 keer herhaling van die woord 'hele' in die groot liefdesgebod ... Dieselfde 4 keer herhaling kom voor in die 'groot' sendingopdrag: alle mag, alle mense, alles doen, altyd Immanuel. Matteus 28:16-20 is al beskryf as die manifesto van die kerk - 'n manifesto wat op dieselfde vlak van waarde lê as die Shema van Israel ... Hierdie manifesto wil vir ons sê hoe nuut anders ons moet dink oor hoe mense inkom en hoe mense binne bly.

(Van Aarde 2006:112-113)

As afsluiting van die Evangelie (waar die twaalftal reeds elf geword het) dien die opdrag om ons te herinner aan die gebrokenheid van dié wat binne is. 'Dit is sulke struikelende mense wat die manifesto aanhoor. En wat in ons ore eggo, is die ambivalensie van om te glo én tegelykertyd te twyfel' (Van Aarde 2006:113).

Volgens Van Aarde (2006:114-117) help Matteus ons om hierdie teenstrydigheid te begryp. Die werkwoord 'gaan' word nie gebruik as selfstandige werkwoord nie, en word nie as opdrag verstaan nie. Dit is soos 'gaan en eet. Die klem lê op die imperatiewe vorm van die hoofwerkwoord: 'maak dissipels (matheteusate), maak die kerk een groot skool van Jesusvolgelinge'. Ons word geroep om die anderkant-mense, die nog-nie-kerk-mense nie, of 'the church on the other side' (vgl. McLaren [1998] 2000:121-143) nie uit die oog te verloor nie.

Samevattend sê Van Aarde (2006) dan:

Die groot sending opdrag berus op twee pilare: Die een om self jou eie ambivalensie raak te sien. Jy glo, maar sukkel om te glo. Dit gaan daarom dat jy jou eie onvermoë sal insien, sodat jy alleen op genade kan bou. Wanneer jy hierdie siening internaliseer, sal jy nie diegene wat jy as buite beskou, met negatiewe vooroordele benader nie. Jy is ook soos hulle. Die tweede is om wat Paul Tillich (1948:118) die 'protestantse beginsel' genoem het, ernstig op te neem ... Die Protestantse beginsel is die moed om alle tradisies, kultureel en kerklik, aan evangeliese kritiek te onderwerp. Dit beteken om jouself in die wêreld te sien, maar nie as so deel van die wêreld dat die wêreld se reëls die evangelie word nie. Dit kan alleen, indien jy die manifesto van Jesus - wat Paulus die 'wet van Christus' noem - in die sentrum plaas. Dit is naamlik om God lief te hê en die een naas jou soos jouself.'

(Van Aarde 2006:117-118)

Deel van die hantering van hierdie dialektiek is om al meer bewus te wees en te wete te kom van die pluralistiese wêreldbewussyn waarvan elke gelowige en die gemeente as sodanig deel is. Dit word ook al makliker namate die lidmate van gemeentes in hierdie bewussyn opgroei. Hulle word met tyd deel daarvan. Dit is hulle bewussyn (vgl. Schweitzer 2004; Newlands 2004).

\section{Paradigmaskuif}

\section{Word dissipels met diens as kernwaarde}

Die teologiese geloofwaardigheid van evangelisasie en missionale kontekstualiteit kan herstel word, die sin daarvan herontdek word en die bediening herstel word wanneer beide teologie en geloofsgemeenskap bogenoemde paradigmaskuif maak: Van gemeente met 'n opdrag tot aflewering van ' $n$ boodskap tot nederige diens in diens van die evangelie van die Koninkryk: maak dissipels van alle nasies. Mense kan terug-gedien word - na Hom wat die lewe aan mense teruggee (vgl. Nel 2002:65-87). By en in Hom 'the true meaning of the human story has been disclosed. Because it is true, it must be shared universally' (Newbigin 1989:125). Song (2006:255-262) dui aan hoedat 'discipleship in Context' self vir die keuse en ontwikkeling van pedagogiese materiaal implikasies het, juis omdat dit behoeftegedrewe en 'receptorcentered' (2006:262) is.

Dit is immers die goeie nuus van die Een wat gekom het nie om gedien te word nie, maar om te dien. Verkuyl (1978) het dit reeds raakgesien:

Het is je voortdurend heroriënteren in je denken, in je emoties, in je gerichtheid, zodat daaruit een nieuwe levensstijl, een nieuwe manier van zijn, en nieuwe gedrag ontstaat van dag tot dag.

(Verkuyl 1978:18)

Volgens Armstrong (1979:38) is dit die bewys van die integriteit en kwaliteit van ons dissipelskap. Dit is die metafoor wat by uitnemendheid die missie van die kerk uitdruk. Ons missie is om dienaars van Christus te wees en te word. Dit is moeilik. Die lewensverhaal van Steve Sjogren (1993) demonstreer hoe kompleks dit is, maar ook hoe God se liefde deur kontekstuele en konkrete dade van vriendelikheid bewys word. Sy definisie van 'servant evangelism' is: 'Servant Evangelism $=$ deeds of love + words of love + adequate time' (1993:22) of 'demonstrating the kindness of God by offering to do some act of humble service with no strings attached' (1993:17-18). Bekering tot dienaar is meer as 'n besluit om diens te lewer. Dit is ' $n$ verandering in die verstaan van wie ons is. Dit het met die herontdekking van identiteit te doen. Ons is nie net tot diens geroep nie. Ons is dienaars wat tot diens geroep is, 'gedwing' deur die liefde (vgl. die radikale boodskap van 2 Kor 5:11-21).

Die titel van die boek van Guder (2000), naamlik The Continuing Conversion of the Church dui ook op die radikaliteit van hierdie paradigmaskuif. Die implikasie van missionale teologie is inderdaad die bekering van die kerk (2000:143f). Of soos hy (2000:26) dit stel: 'Evangelizing churches are churches that are being evangelized. For the sake of its evangelistic vocation, the continuing conversion of the church is essential.' In die woorde van Newbigin (1989:227): 'I am suggesting that the only answer, the only hermeneutic 
of the gospel, is a congregation of men and women who believe it and live it.' Dit is juis waarom dit in die opbou van 'n missionêre gemeente gaan (vgl. Nel 1994, 2004). Michael Green het reeds in 1990 'n boek van 574 bladsye laat verskyn onder die titel Evangelism through the local church. Die hoofstuk oor 'Evangelism in a Multi-Faith Society' is vir ons onderwerp van besonderse belang (1990:43-78). Vir enigiets in lyn met die evangelie van die Koninkryk moet hierdie gemeente verander tot 'een groot skool van Jesus-volgelinge' (Van Aarde 2006:114; vgl. ook Weth 1998; Drescher-Pheiffer 2001).

\section{Samevattend}

Callahan (1983) publiseer sy eerste navorsingsresultate na 25 jaar se empiriese kontak en analises in 750 gemeentes. Hy bevind dat gemeentes wat in hulle omgewings 'n verskil maak (effektiewe gemeentes in sy taal) minstens drie spesifieke, kontekstuele en konkrete missionêre projekte het. Na nóg 250 gemeentes en vyf jaar later ontwikkel hy die werkboek en beskryf hierdie drie missionêre projekte as bedieninge wat 'effektiewe hulp verleen, goed bekend is aan en waardeer word deur die gemeenskap' (Callahan 1987 [1991]:14, aangehaal uit die Afrikaanse vertaling; vgl. ook Callahan 2010:53-68). Ott (2004) argumenteer vir hierdie verandering van die gemeente tot ' $n$ bedieningsgemeenskap waar hulle is (vgl. ook Hastings 2007 vir 'n prakties-teologiese beskrywing en voorbeelde van kontekstuele beïnvloeding in Japan). Hoewel verteenwoodigers van gemeentes ('sendelinge') namens 'n gemeente elders 'n betekenisvolle verskil kan gaan maak, kan die gemeente self eintlik net in konteks die verskil maak - of ten minste sover as wat die lidmate per week beweeg. Callahan (1987:12, 2008:9) het 'n bekende formule in hierdie opsig verfyn ten einde gemeentes te help om hierdie kontekstuele ruimte (radius) te bepaal. In persoonlike kontak met 115 gemeentes waar ek gemeenteanalises kon lei, is hierdie radius van plaaslike gemeentes in Suid-Afrika gemiddeld $15 \mathrm{~km}-20 \mathrm{~km}$. Dit is die primêre invloedsfeer en -ruimte van die gemeente.

Die argument is dus nie of gemeentes ook by die wyer en 'ver' wêreld betrokke moet raak nie. Dit lyk my selfs na 'n futiele vraag. Gemeentes kan en moet selfs. Die saak ter tafel is dat selfs so 'n gemeente missionale integriteit verloor indien hy nie kontekstueel relevant is nie.

\section{Erkenning \\ Mededingende belange}

Die outeur verklaar dat hy geen finansiële of persoonlike verbintenis het met enige party wat hom nadelig kon beïnvloed in die skryf van hierdie artikel.

\section{Literatuurverwysings}

Abraham, W.J., 2001, The logic of evangelism, Eerdmans, Grand Rapids, MI. Armstrong, R.S., 1979, Service evangelism, Westminster, Philadelphia, PA. Armstrong, R.S., 1987, Faithful witnesses: Leader's guide, Geneva, Philadelphia, PA. Barth, K., 1932, 'Die Theologie und die Mission in der Gegenwart', Zwischen den Seiten 10, 189-215.
Berneburg, E., 1997, Das Verhältnis van Verkundigung und sozialer Aktion in der evangelikalen Missionstheorie, Brockhaus, Wuppertal.

Blauw, J., 1962, The missionary nature of the church, Eerdmans, Grand Rapids, MI.

Bohren, R., 1974, Predigtlehre, Chr Kaiser, München.

Bosch, D.J., 1991, Transforming mission: Paradigm shifts in theology of mission, Orbis, Maryknoll, NY.

Bosch, D.J., 1993, God's reign and the rulers of this world: Missiological Reflections on Church-State relationships, in C. van Engen, D.S. Gilliland \& P. Pierson (eds.), The good news of the kingdom: Mission theology in the third millennium, pp. 89-95, Orbis, Maryknoll, NY.

Boshoff W.S., 2011, 'Gemeentebou en die begeleiding van rouprosesse in ' $n$ konteks van omvattende verandering: Stemme uit drie gemeentes van die NG Kerk se Noordelike Sinode', Phd-proefskrif, Departement Praktiese Teologie, Universiteit van Pretoria.

Bradshaw, B., 1993, Bridging the gap: Evangelism, development and sjalom, MARC, Monrovia, CA.

Brouwer, R., 2009, Geloven in gemeenschap: Het verhaal van een Protestantse Geloofsgemeenschap, Kok, Kampen.

Callahan, K.L., 1983, Twelve keys to an effective church, Harper \& Row, San Francisco, CA.

Callahan, K.L., 1987 [1991], Twelve keys to an effective church: The planning workbook Harper \& Row, San Francisco, CA. (Oorspronklike Afrikaanse vertaling 1991 deur M. Nel \& J.J. Louw, 4de druk 2008 en geredigeer deur S.J. le Roux.)

Callahan, K.L., 2010, Twelve keys to an effective church: Strong, Hhealthy congregations living in the grace of God, 2nd edn., Jossey-Bass, San Francisco, CA.

Conradie, E.M., 2010, 'Creation at the heart of mission?', Missionalia 38(3), 380-396.

Ekström, B., 2003, 'The kingdom of God and the church today', Evangelical Review of Theology 27(4), 292-305.

Dick, D.R., 2007, Vital signs: A pathway to congregational wholeness, Discipleship Resources, Nashville, TN

Dingemans, G.D.J., 1986, In die leerschool van het geloof, Kok, Kampen.

Drescher-Pheiffer, K.H., 2001, Diakonische Gemeinde in der Grossstadt zwischen Kreuzerfahrung und Verheissing des Reiches Gottes, Lang, Frankfurt am Main.

Gibbs, E., 2000, ChurchNext: Quantum changes in how we do inistry, Intervarsity, Downers Grove, IL.

Green, M., 1990, Evangelism through the local church, Hodder \& Stoughton, London.

Guder, D.L., 2000, The continuing conversion of the church, Eerdmans, Grand Rapids, MI.

Harris, M., 1988, 'Teaching: Forming and transforming grace', in C.E. Nelson (ed.), Congregations: Their power to form and transform, pp. 238-264, John Knox, Atlanta, GA.

Hamman, J.J., 2005, When steeples cry: Leading congregations through loss and change, Pilgrim, Cleveland, $\mathrm{OH}$.

Hastings, T.J., 2007, Practical Theology and the one body of Christ: Towards a missional-ecumenical model, Eerdmans, Grand Rapids, MI.

Hendriks, H.J., 2004, Studying ongregations in Africa, Lux Verbi, Wellington.

Hunsberger, G.R., 1998, Baring the witness of the Spirit: Leslie Newbigin's theology of cultural plurality, Eerdmans, Grand Rapids, MI.

Kiefert, P., 2007, Ons is nou hier: 'n Nuwe ere van gestuur-wees, Lux Verbi BM, Wellington.

King, P., 1996, Good News for a suffering world, Monarch, Crowborough.

Kromminga, C.G., 1964, The communication of the gospel through neighboring, Wever, Franeker

Kromminga, C.G., 1976, Bringing God's news to neighbors, Baker, Grand Rapids, MI.

Mclaren, B.D., [1998] 2000, The church on the other side: Doing ministry in a postmodern matrix, Zondervan, Grand Rapids, MI. (Die 1998-publikasie was getiteld Reinventing your church.)

Moynagh, M., 2001, Changing world, Changing church, Monarch, London.

Nel, M., 1994, Gemeentebou, Orion, Halfway House.

Nel, M., [1997] 2000, Jeugbediening: 'n Inklusiewe gemeentelike benadering Barnabas, Bloemfontein. (Die 1997 uitgawe is uitgegee deur die RGN, Pretoria.)

Nel, M., 2002, 'Serving them back. Making a case for service evangelism in youth evangelism, Journal of Youth and Theology 1(1), 65-87.

$\mathrm{Nel}, \mathrm{M} ., 2004$, Who are we? Understanding and finding identity in the local church, Kitskopie, Pretoria.

Nel, M., 2006a, Stories van hoop, CUM, Vereeniging.

Nel, M., 2006b, 'Geskenke wat ' $n$ verskil maak', in M. Nel (red.), Stories van hoop, pp. 11-28, CUM, Vereeniging.

Nel, M., 2007, 'Verantwoordelike evangelisasie in die teenwoordigheid van God: 'n Teologiese refleksie', Praktiese Teologie Suid-Afrika 22(1), 98-117.

Nel, M., 2009a, 'Congregational analysis revisited: Empirical approaches', HTS Teologiese/Theological Studies 65(1), 230-242. http://dx.doi.org/10.4102/hts. v65i1.187

Nel, M., 2009b, 'Congregational analysis: A theological and ministerial approach', HTS Teologiese Studies/Theological Studies 65(1), 432-448. http://dx.doi. org/10.4102/hts.v65i1.303 
Nel, M. \& Ungerer, A.G., 2011, 'Die verband tussen gemeentebouprosesse en missionale gemeenteontwikkeling', HTS Teologiese Studies/Theological Studies 67(2), Art. \#931, 11 pages. http://dx.doi.org/10. 4102/hts.v67i2.931

Nelson, C.E., 1988a, 'Why this book on congregations', in C.E. Nelson (ed.), Congregations: Their power to form and transform, pp. 1-19, John Knox, Atlanta, $\mathrm{GA}$.

Nelson C.E., 1988b, Congregations: Their power to form and transform, John Knox Atlanta, GA.

Newbigin, L., 1983, The other side of 1984: Questions for the churches, World Council of Churches, Geneva.

Newbigin, L., 1989, The gospel in a pluralist society, Eerdmans, Grand Rapids, MI.

Newbigin, L., 1995, The open secret: An introduction to the theology of mission, rev. edn., first published in 1978, Eerdmans, Grand Rapids, MI.

Newlands, G., 2004, The transformative imagination: Rethinking intercultural theology, Ashgate, Hampshire.

Niemandt, C.J.P., 2010, 'Kontoere in die ontwikkeling van 'n missionêre ekklesiologie in die Nederduitse Gereformeerde Kerk - 'n omvangryker vierde golf', Nederduits Gereformeerde Teologiese Tydskrif 51(3\&4), 92-103.

Nouwen, H.J.M., 1994, The return of the prodigal son: A story of homecoming, Doubleday, NY.

Ott, E.S., 2004, Transform your church with ministry teams, Eerdmans, Grand Rapids, $\mathrm{MI}$.

Prill, T., 2005, 'Evangelism, theology and the church', Evangelical Review of Theology 29(4), 309-330.

Saayman, W., 2007, Being missionary - Being human: An overview of the Dutch Reformed Mission, Cluster, Pietermaritzburg.
Schippers, K.A., 1982, 'Werken aan de gewone gemeente, 1', Praktische Theologie 2 96-105.

Schweitzer, F.L., 2004, The postmodern life cycle: Challenges for church and theology, Chalice, St Louis, MO.

Sellon, M.K., Smith, D.P. \& Grossman, G.F., 2002, Redeveloping the congregation: A how to for lasting change, Bethesda, Alban.

Sjogren, S., 1993, Conspiracy of kindness, Servant, Ann Arbor, MI.

Song, M., 2006, 'Contextualization and discipleship: Closing the gap between theory and practice', Evangelical Review of Theology 30(3), 249-263.

Tillich, P., 1948, The Protestant era, University of Chicago, Chicago, IL.

Van Aarde, A.S., 2006, 'Hoe om in te kom en hoe om binne te bly - die "groot sendingopdrag" aan die kerk vandag volgens Matteus 28:16-20', HTS Teologiese Studies/Theological Studies 62, 103-122.

Van Ruler, A.A., 1969, Theologisch Werk I, Nijkerk, Callenbach.

Van Ruler, A.A., 1973, Theologisch Werk VI, Nijkerk, Callenbach.

Verkuyl, J., 1978, Inleiding in de Evangelistiek, Kampen, Kok.

Verkuyl, J., 1993, 'The Biblical notion of Kingdom: Test of validity for theology of religion', in C. van Engen, D.S. Gilliland \& P. Pierson (eds.), The good news of the Kingdom: Mission theology in the third millennium, pp. 71-81, Orbis, Maryknoll,

Walzer, M., 1966, The revolution of the saints: $A$ study in the origins of radical politics, Weidenfeld \& Nicolson, London.

Weth, R. (Hrsg.), 1998, Wat hat die Kirche heute zu sagen: Auftrag und Freiheit der Kirche in der pluralistischen Gesllschaft, Neukirchen Verlag, Neukirchen-Vluyn. 